\title{
THE GLOBALIZATION EFFECT OF LAW AND ECONOMIC ON CYBERCRIME
}

\author{
Advento Jeronimo \\ Oriental Timor Lorosae University \\ adyjeronimo@yahoo.com
}

\begin{abstract}
The globalization of law and the economic has led to developing countries' regulations on investment, trade, services, information technology, and other economic fields approaching developed countries (converagence), as well as the regulation of cyber space activities that cannot be separated from relations with other countries. Norms of law between nations increasingly play an important role, especially how to regulate all forms of advancement in information technology, communication and transportation. This is inseparable from the foreign policy that has been woven between nations so far. The regulation of cyber crime in legislation is absolutely necessary. Related to the jurisdiction of this crime which is a global crime, it is necessary to have its own law governing cyber crime, namely cyber law, which also regulates its jurisdiction by including the principle that allows cyber criminals to harm the state even though it is outside the state territory.
\end{abstract}

Keywords: Cybercrime; Globalitation effect, Law and Economic.

\section{A. INTRODUCTION}

The progress of science and technology is developing so rapidly. All aspects of human life are inseparable and cannot even be separated from technological development. Especially entering the era of globalization, where various patterns of change are offered or sold by the world market and any nation, so that people who are in different parts of the hemisphere continue to reap the impact in accordance with the information and changes that are penetrated. Through the globalization of information that has truly entered homes, schools and religious institutions, people are dragged into accessing and enjoying various forms of information on the cultural revolution in other countries or nations on earth.

Globalization is usually considered always only related to the economy that involves global relations. But the truth is that globalization is not just about economic interdependence, but more about the problem of transformation of time and space in human life. Events that occur in distant places, whether related to the economy or not, affect the community directly and immediately, compared to previous times. This is inseparable from the services of the communication revolution and the spread of information technology. ${ }^{1}$

1 Setyo Utomo, Pengaruh Pembangunan Di Era Globalisasi Terhadap Pemenuhan Hak 
Globalization in this case can be said to be a major shift from economic and political power which is mainly due to technological inventions. Barbara Parker gives the definition of globalization as follows: ${ }^{2}$

There is a growing sense that events occuring throughout the world are converging rapidly to shape a single, integrated world where economic, social cultural, technological, business other influences cross traditional borders and boundaries such as nations, national cultures, time, space, and business industries with increasing ease.

There is an increase in the meaning that events around the world converge quickly to form a single and integrated world where economic, social, cultural, technological, business, and others influence traditional boundaries such as the state, national culture, time space and the business industry increases easily.

Globalization touches all the important aspects of life. Globalization creates various challenges and new problems that must be answered, solved in an effort to utilize globalization for the benefit of life. Globalization itself is a term that emerged around twenty years ago, and began to be so popular as a new ideology for the last five or ten years. As a term, globalization is so easily accepted or known by people all over the world. The discourse of

Asasi Manusia Atas Lingkungan Hidup Yang Baik Dan Sehat, Jurnal Pembaharuan Hukum, Volume I No. 3 SeptemberDesember 2014, P.258-266

2 Ngadino, peranan hukum dalam globalisasi ekonomi, Jurnal Pembaharuan Hukum, Volume I No.1 Januari-April 2014, P.59-65 globalization as a process is marked by the rapid development of science and technology so that it is able to fundamentally change the world. ${ }^{3}$

Globalization is widely understood as stretching social, political and economic activities across borders so that events, decisions and activities that take place in a place or region have an important meaning for society as a whole. ${ }^{4}$

Globalization is a consequence that cannot be avoided by any country. Globalization makes a world without borders, countries compete freely in various fields, and sometimes beyond the jurisdiction of a country. Globalization of the world is seen as a result of the development of information technology, especially in the use of cyberspace (cyber space) as an electronic communication media to spread information throughout the world. The discovery of information technology has an impact on several aspects of a country, such as national sovereignty, for example in relation to removing barriers to trade with criminal cases in cyberspace.

One of the products of science and technology is information technology or commonly known as telecommunications technology. In its development, with the discovery of computers as products of science and technology. Then there was a convergence between

3 Nurhaidah, M. Insya Musa, Dampak Pengaruh Globalisasi Bagi Kehidupan Bangsa Indonesia, Jurnal Pesona Dasar Universitas Syiah Kuala Vol. 3 No. 3, April 2015, P.1- 14

4 Nikolopoulou, 2010, Education for Sustainable Development: challenges, strategies, and practices in a globalizing world, Vivek Mehra, New Delhi,P.38 
telecommunications, media and computer technology. The convergence of communication technology, media and computers produces a new tool called the internet. Technological progress which is the result of human culture, in addition to having a positive impact, in the sense that it can be utilized for the benefit of mankind also brings a negative impact on human development and civilization, namely storing vulnerability which is certainly very dangerous, namely the emergence of crime in cyberspace which has become a reality the world community known as cyber crime.

Crimes using technology, namely information technology, especially computers and the internet (cyber crime) have reached an alarming stage. Advances in information technology, in addition to bringing into the revolutionary business world (digital revolution era) which is completely practical, turns out to have a terrible dark side, such as pornography, computer crime, even digital terrorism, garbage information warfare, and hackers.

This crime is transnational, so it requires proper regulation to fight this crime that crosses the jurisdiction of a country, because this crime brings enormous losses in various fields, namely political, economic, social, cultural, and defense and security. Jurisdiction is a state's authority to carry out regulations that are manifested in executive, judicial and legislative authority. A country has the authority to make arrangements for all individuals (ius in personam), objects (ius in rem), as well as events that fall within the scope of their legal authority. The jurisdiction is not only limited to the physical geographical or scope of the state, but can be applied to things / objects that are outside its territory.

In the current era of globalization, legal norms between nations increasingly play an important role, especially how to regulate all forms of advancement in information technology, communication and transportation. The three sides of progress eliminate all forms of distance, time and space. With all that, geographical constraints no longer apply. This is inseparable from the foreign policy that has been woven between nations so far. So, between law and politics can not be separated, especially in this era of globalization with all the sophistication offered.

Politics and law as social subsystems are in a position of equal determination between each other, because even though law is a product of political decisions, but once the law exists, all political activities must be subject to the rule of law.

In historical studies, if examined carefully from any existing legal concepts, it is always inseparable from the influence of political and economic conditions. Therefore in addition to political conditions, in making and implementing laws, in addition to conventional considerations such as justice, legal certainty, order, human rights, morality, also considering economic interests, as well as considering the extent of the consequences arising from the source of the problem.

Cyber crime as an impact of globalization that causes a lot of losses in various fields, the handling must be maximized, given the 
perpetrators of violations often become difficult to be snared because the law and the court does not have jurisdiction against perpetrators and legal actions that occur, given the violation of the law is transnational but the result actually has implications law in the country.

\section{B. DISCUSSION}

\section{The Globalization Effect Of Law And Economic On Cybercrime}

In the era of
globalization, information
technology plays a very
important role. By mastering
technology and information, a
country has sufficient capital to
become a winner in global
competition. Community life at
this time, slowly began to
experience a very big change. This change is a change in the industrial era into the era of technology and information behind the influence of the advancing era of globalization that makes computers, the internet, and the rapid development of information technology as a major part that must or should not be lacking in people's lives today, because in the era of globalization, if not mastering information technology is identical to illiteracy.

From the beginning, people have always been looking for convenience in carrying out activities in achieving needs. This has been fulfilled with technological advancements. Even so, people are still not satisfied, so they always look for the possibility of convenience in meeting their needs. On the other hand, in achieving their needs, it often happens that someone actually does something despicable. These technological advancements have caused profound changes in the lives of humankind with all civilizations and cultures. ${ }^{5}$

The advancement of technology and information which is marked by the emergence of the internet, and is the result of a technological revolution that collaborates synergistically with information and computer technology, in its development has led to rapid changes in the structure of society from agrarian to industrial, industrial to information, which in turn brings and creates patterns, models and new lifestyles in a new world, namely cyberspace (cyber).

The internet has been integrated with human activities ranging from small and simple activities to important and complex activities. This reality is a plus of technology. With internet technology services, many companies carry out several business activities such as online marketing, distance selling, and e-commerce.

Technology is an activity that is born by humans by

5 Hendro Setyo Wahyudi, Mita Puspita Sukmasari, Teknologi Dan Kehidupan Masyarakat, Jurnal Analisa Sosiologi, April 2014, 3 (1), P. 13-24 
planning and creating material objects of practical value, such as cars, planes, television, which are the results of technological development. Judging from the function and importance of technology, all sections of society and government institutions are very dependent on technology both for positive and negative things. The word cyber and technology are elaborated from the origin of the word technique, from the Greek word Technikos which means art or skill in and logos are the limo or the main principles of cyber (software). Increased utilization of cyberspace in all lines of community life in the current era of globalization in parallel, will link to the use of an internet technology network on certain objects or sectors in accordance with the objectives of its supervision. ${ }^{6}$

Another example with the use of internet media as a supporting means in booking / booking tickets (airplanes, trains), hotels, payment of telephone bills, electricity, has made consumers more comfortable and safe in carrying out their activities. Consumers do not need to leave the house and queue to get the desired service because the booking / reservation process can be done in the

6 Ineu Rahmawati, The Analysis Of Cyber Crime Threat Risk Management To Increase Cyber Defense, Jurnal Pertahanan \& Bela Negara, Volume 7 Nomor 2 Agustus 2017, P. 51-66 house, office, even in a vehicle, as well as the level of security in transactions is relatively guaranteed because transactions are done online. The economic globalization network activity caused by the advancement of information technology not only changes the pattern of economic productivity but also increases the level of productivity, and at the same time also causes structural changes in political life, culture, social life of society and also the concept of time in various layers of society.

Information technology, besides having a positive impact, turns out to have a negative impact on the social lives of its user communities. This negative impact is called the dark side of advanced technology. This negative impact is the emergence of a variety of anti-social behavior, deviant behavior, and crime along with the internet in cyberspace.

The emergence of crime in cyberspace or cybercrime is a justification, that this global era is identical with the era of ferocious mines. An imaginary and virtual space, an area or zone for each person to carry out activities that can be carried out in everyday social life in an artificial manner. Everyone can communicate with each other, enjoy entertainment, and access anything that he thinks can bring pleasure or perhaps 
satisfaction. There are various offers in cyberspace according to global information sold by capitalists who are willing to justify any means for profit. Even ironically, they also intend to undermine the moral, ideological, and religious endurance of other nations on earth that are different from themselves.

Information technology and telecommunications have succeeded in changing the order and pattern of production, trade and investment from multinational companies and global companies.

Radically, cyber space has changed the relationship between legally significant (online) phenomena and physical location. The increase in global computer networks (global computer network) has destroyed the relationship between geographical location and:

a. The authority of the government to impose control over online behavior;

b. The influence of online behavior on individuals or goods;

c. Government legitimacy to regulate global phenomena; and

d. The ability of the territory to notify people who cross the border about applicable law.

This radical change as stated by Jessica Lipnack and Jeffrey Stamps is smash the boundaries, tear down the hierarchy and dismantle the bureaucracy. Of course this change causes anything that comes into contact with this information technology to be adjusted, so that globalization also demands changes in trade, investment, information technology, and so on policies that provide more flexibility for capital, technology, and labor to move easily between territorial sovereignty of the country.

It is not wrong if globalization demands so, because it is associated with the advancement of information technology that creates cyber crime, the potential to cause harm in several fields such as political, economic, social and cultural which is significantly more alarming than other highintensity crimes and even in the future. can disrupt the national economy through infrastructure networks that are based on electronic technology (banking, telecommunications, satellites, electricity networks, and aviation traffic networks).

Considering the nature of the internet that transcends national boundaries, solves the problem of time and place and operates in cyberspace, the internet gives birth to various forms of activities that are not fully regulated by the existing law. This fact has made people aware of the need for regulations governing activities on the internet. that internet 
technology is directly related to changing patterns of daily life, including ways of working, access and exchange of information, shopping, meeting people, and maintaining and managing existing social relationships. The existence of the internet makes it easy for someone to communicate without being limited by space and time. ${ }^{7}$

In a state of law (rechtstaats and rule of law), power which is a reflection of politics manifested in every policy requires a legal / regulatory basis so that the validity of the (political) policy can be justified. In a global context, legal politics cannot merely protect national interests, but must also protect cross-national interests, as it relates to cyber crime that is cross-country in nature. The development of increasingly sophisticated technology must be accompanied by several impacts, both positive and negative impacts. ${ }^{8}$

The globalization of law and politics has led to developing countries' regulations on investment, trade, services, information technology, and other economic fields approaching developed countries

7 Selwyn, Neil, 2011, Education and Technology Key Issues and Debates, Replika Press Pvt Ltd, India, P.35

8 Sudarsri Lestari, Peran Teknologi Dalam Pendidikan Di Era Globalisasi, edureligia Vol. 2, No. 2, Juli-Desember 2018, P.94100 (converagence), as well as the regulation of cyber space activities that cannot be separated from relations with other countries.

The urgency of national arrangements for activities in cyber space is based on three main ideas, namely:

a. The need for legal certainty for perpetrators of activities in cyber space because it has not been adequately accommodated in the existing regulations;

b. Efforts to anticipate the implications caused by the use of information technology; and

c. The existence of global variables, namely free competition and open markets (WTO / GATT). Generally a society undergoing change due to technological advancements generates many social problems. This happens because the condition of the community itself is not ready to accept changes or it can be because the community values have changed in assessing the old condition as a condition that is no longer acceptable.

These legal issues are very closely related to the development of information technology regulation (cyber space) today. As it is known that in facing the era of information technology that is increasingly fast without being limited by time and territory of the country (timeless and borderless), law in Indonesia is 
very far behind, many problems that have not been solved through this legal instrument.

The development of the legal sector is expected to be able to contribute to the development of the information technology era and accelerate economic development. The general condition in Indonesia does not yet support Indonesia's readiness in facing global competition at this time. The effect of the law on the acceleration of economic development in Indonesia plays a very strategic role, through the legal instruments of all economic activities in its various manifestations, having a legal basis. Through legal instruments, protection in activities has become increasingly guaranteed.

The development of today's era of society is industrialization, and supported by the development of telecommunications technology, the relations between countries are of a worldwide nature which creates a new world order. All economic activities carried out without a strong legal basis will easily lead to various problems, which if calculated economically (profit and loss) will generate high costs.

The desire for a safe and clear international trade climate for the international community and to create sustainable trade liberalization in the fields of investment, labor, services to encourage increased economic growth and development worldwide, has begun since the establishment of the GATT through a series of negotiations that leading to the formation of the World Trade Organization (WTO).

Security and clarity (certainty) in transactions cannot be ignored in ensuring the continuity of transactions, especially in the current era of globalization, where trade transactions are no longer limited by differences in distance, national background, legal system, position, capital, education level, domicile, and so on.

Problems that arise if not immediately addressed will give birth to various conflicts that cause the purpose of the transaction to be unmet, both in terms of economic and good relations. Legislation / law as a part of supporting elements of economic development activities can make a significant contribution to the acceleration of economic development. Economic development requires a solid legal foundation, so that the existence of legislation has a positive influence.

Regulations in the field of information technology which are comprehensive in nature must contain all problems related to their utilization, such as legal, economic, institutional, dispute resolution, and so on. The regulation of information technology will facilitate the 
development and evaluation of the use of such technology.

Associated with the regulation of information technology (cyber space), there are factors driving the need for immediate establishment of laws governing activities in cyber space, including:

a. Factual conditions that show almost every human life has been influenced by the activity of utilizing information technology. Starting from the needs of children to the needs of adults, ranging from household equipment to the needs of state defense and security, so it is ironic that for such a complex activity there are no laws governing it;

b. Existing regulations (the existing law) have not been able to answer the problems that arise in the field of information technology. The logical consequence of this situation is that the use of technology is hampered;

c. There are concerns from some circles (especially those involved in the business world), regarding the absence of legal guarantees in their activities through information technology facilities if the regulation in question has not been established. It is important to know that safety in activities is one of the determining factors for the creation of a good business climate; d. Indonesia as a part of the world community cannot avoid fixing its legal instruments, especially those relating to information technology, so that they are not excluded from the international arena;

e. Competition in fighting over foreign investment has been increasingly fierce, many countries in the world in an effort to attract foreign investors to enter the country provide various kinds of facilities. The unpreparedness of a country to draft an information technology law is one of the factors inhibiting the entry of foreign investment.

Therefore, in its implementation the parties tend to reduce tax expenditure wherever possible. In transactions with the internet it is possible to have multiple taxes, because the tax subject in his country has been taxed, while in other countries taxes are also imposed on the transactions that he does.

Likewise the need for clarity of any activities that can be subject to tax, the tax aspect also requires clarity of regulation of the information technology law, so that businesses in the field of information technology do not undermine their intention to invest in Indonesia due to unclear taxation arrangements. Globalization facilitates human relations, including in 
establishing diplomatic
cooperation with other countries. This is possible because cooperation, both in trade and in politics is able to make Indonesia better known by other nations, through direct and indirect visits and communication, able to strengthen relations between two or more countries. So, if a country does not want to be alienated by the world community, it must be willing to open up so as not to be left behind in any case. Globalization makes it possible to make countries more open to the economy of a nation and even in terms of the ratification of certain laws to overcome transnational problems. One of them is cooperation in dealing with cyber crime.

The influence of
globalization on the
advancement of information technology can, among others, be able to develop technology and information at an international level, be able to utilize technology to publicize the potential of the Indonesian state, and open access to information from the international world as a comparative study and as a collaboration with other countries. In addition, as mentioned earlier, information technology also has a negative side, namely the emergence of a new type of crime called cyber crime. Because cyber crime is cross country and causes huge losses, in handling this cyber crime international cooperation is needed in overcoming it as a form of Indonesian foreign policy so that the risk of political stability is maintained, which is then regulated in several international conventions or agreements. Indonesia complies with these legal regulations and international treaties, ratifies international legal treaties on cyber crime, and respects international justice and cooperates with Interpol.

Cybercrime has been become a major portion for law enforcement agencies and intelligence services to both national and international nonpratisi exception practitioners of business, the merchant, the customer, to the end-user. In most cases, Internet crime begins by exploiting the hosts and computer networks therefore the swindlers and entruder coming across networks, especially networks based on TCP/IP protocol.

Advances in technology have brought about changes and rapid shifts in a life without limits. Utilization of these technologies have encouraged rapid business growth, due to a variety of information can be presented via a long distance relationship and those who want to enter into transactions do not have to meet face to face, but simply through a computer and telecommunications equipment. Developments in information 
technology also establish a new world society that is no longer hindered by territorial boundaries and have reversed everything away so close to the imaginary so real. But behind the progress it has also spawned new unrest-unrest with the advent of sophisticated crime in the form of cyber crime. $^{9}$

The influence of globalization in the order of Indonesia's national law is so large, it must be balanced with the strong desire of all Indonesian people in the framework of developing a better national law. This is increasingly understandable given that globalization is a symptom that cannot be denied or avoided by any country that does not want to be isolated in the international community.

\section{CONSLUSION}

Globalization of technology in law and economics is seen as a result of the development of information technology, especially in the use of cyberspace (cyber space) as an electronic communication media to spread information throughout the world. This change causes anything that comes into contact with this information technology to be adjusted, so that globalization also demands changes in trade, investment, information technology, and so on policies that provide more flexibility for capital, technology, and labor to move easily between sovereignty country territory.
9 Andri Winjaya laksana, Cybercrime Comparison Under Criminal Law In Some Countries, Jurnal Pembaharuan Hukum, Vol V No.2 April - Agustus 2018, P.217-226. 


\section{BIBILIOGRAPHY}

\section{Books:}

Andri Winjaya laksana, Cybercrime Comparison Under Criminal Law In Some Countries, Jurnal Pembaharuan Hukum, Vol V No.2 April-Agustus 2018;

Hendro Setyo Wahyudi, Mita Puspita Sukmasari, Teknologi Dan Kehidupan Masyarakat, Jurnal Analisa Sosiologi, April 2014, 3 (1);

Ineu Rahmawati, The Analysis Of Cyber Crime Threat Risk Management To Increase Cyber Defense, Jurnal Pertahanan \& Bela Negara, Volume 7 Nomor 2 Agustus 2017;

Ngadino, peranan hukum dalam globalisasi ekonomi, Jurnal Pembaharuan Hukum, Volume I No.1 Januari-April 2014;

Nikolopoulou, 2010, Education for Sustainable Development: challenges, strategies, and practices in a globalizing world, Vivek Mehra, New Delhi;

Nurhaidah, M. Insya Musa, Dampak Pengaruh Globalisasi Bagi Kehidupan Bangsa Indonesia, Jurnal Pesona Dasar Universitas Syiah Kuala Vol. 3 No. 3, April 2015;

Selwyn, Neil, 2011, Education and Technology Key Issues and Debates, Replika Press Pvt Ltd, India;

Setyo Utomo, Pengaruh Pembangunan Di Era Globalisasi Terhadap Pemenuhan Hak Asasi Manusia Atas Lingkungan Hidup Yang Baik Dan Sehat, Jurnal Pembaharuan Hukum, Volume I No. 3 September-Desember 2014;

Sudarsri Lestari, Peran Teknologi Dalam Pendidikan Di Era Globalisasi, edureligia Vol. 2, No. 2, Juli-Desember 2018; 